\title{
Can Education Transform Our World? Global Citizenship Education and the UN's 203o Agenda for Sustainable Development
}

\author{
Joel Westheimer
}

To refuse to face the task of creating a vision of a future ... immeasurably more just and noble and beautiful than ... today is to evade the most crucial, difficult, and important educational task.

GEORGE COUNTS (1932)

\section{$\mathbf{1}$ \\ Introduction}

Belief in the fundamental importance of education for improving society has been long-standing. Across more than a century of school reform around the world, the idea that young people must learn to be good stewards of their communities has concerned scholars and policymakers alike (Dewey, 1916; Educational Policies Commission, 1940; Gutmann, 1987; Soder, 1996; Parker, 2003; Walling, 2004; Noddings, 2015; Apple, 2018). So, it is not entirely surprising that the United Nations' Sustainable Development Goals (SDGs) see education as a key element of global transformational change (UNGA, 2015b).

SDG 4 seeks inclusive, equitable, quality education for all children and young adults, and aims to reach a set of 10 targets for education worldwide by 2030 (UNGA, 2015 b, pp. 19-20). Other chapters in this book address a diverse set of aims represented in these targets, including, for example, adequate financing (Chapter 8 by David Archer and Tanvir Muntasim), gender equality (Chapter 3 by Naureen Durrani and Anjum Halai), disability (Chapter 4 by Christopher Johnstone, Matthew Schuelka, and Ghada Swadek), assessment (Chapter 12 by Clara Fontdevila), and the rights of students to receive an education that is free of a profit motive (Chapter 7 by Alexandra Draxler). These are all important parts of pursuing equity and access to quality education for all children. My focus in this chapter is on the role of global citizenship education in pursuing 
those and other similar aims. While policymakers have often looked to schools to provide students with the knowledge and skills they need to secure productive employment and flourish economically, I will be concerned with a different lever for change: the potential for education to foster a more just and sustainable society for all by preparing students to be civically and politically engaged citizens.

School is not only a vehicle for the transmission of knowledge but also a place where children learn about the society in which they are growing up, how they might engage productively, how they can fight for change when change is warranted, and how to know when it is warranted. For that reason, the goals, content, and methods of educational programmes are highly contested. How a country schools its children is a reflection of its collective principles and ideals. In particular, to speak of citizenship education (global and otherwise) is to speak not only of the world as we see it, but also, and more importantly, of the global society that we hope the next generation will help to create. Ideas about what makes a 'good' citizen are a proxy for a vision of the good society, and agreeing on common elements of a good society is a challenging undertaking for even one nation state. To extend that challenge to a quest for a common vision among all the earth's nations invites certain contention, and yet is an essential element of any agenda for global change. This chapter, then, has implications well beyond SDG 4. As I argue in what follows, if we seek the kind of lasting progress called for by the 2030 Agenda for Sustainable Development, educators must be empowered to engage youth and young adults in a vision of change and equip them with the tools they need to get there.

Are we teaching children to unquestioningly preserve social, political, and economic norms and behaviours, or to imagine and pursue new and better ones? Do we teach them only the importance of following the rules or also to question when the rules are not worth following? Do we teach students to mobilise in support of policies that promote only their own self-interest, or to think more broadly about their ethical obligations to others? If today's youth are to participate in political decision-making and in efforts to move toward more sustainable social, political, and economic arrangements, schools must ensure that they are sufficiently well-informed to do so effectively.

John Dewey (1916) described schools as miniature communities and noted that the school is not only a preparation for something that comes later but also a community with values and norms embedded in daily experiences. Transforming the way we teach citizenship (local, national, and global) then, is not only the purview of the civics and social studies classroom, but a journey into all classrooms, all subjects, and the entire school experience. Schools teach lessons in citizenship regardless of whether or not they follow a citizenship 
education curriculum. How classrooms are set up, who gets to talk when, how adults conduct themselves, how decisions are made, how lessons are enacted all these inevitably serve as lessons in citizenship. Whether teachers explicitly 'teach' lessons in citizenship or not, students learn about community organisation, the distribution of power and resources, rights, responsibilities, and of course, justice and injustice.

SDG 4, in its broadest sense, is about worldwide equity and access to quality education. But its specific target goals reach further and are tied to all 17 goals for a sustainable world. By 2030, Target 4.7 declares, all learners should 'acquire the knowledge and skills needed to promote sustainable development, including, among others, through education for sustainable development and sustainable lifestyles, human rights, gender equality, promotion of a culture of peace and non-violence, global citizenship and appreciation of cultural diversity' (UNGA, 2015b, p. 17). Global citizenship education, as illustrated in Target 4.7 , is a central part of SDG 4, but it is also a precondition for many of the other goals and targets in the 2030 Agenda. SDG 4 seeks to promote well-being for all at all ages; SDG 10 calls for reducing inequality between and within countries; SDG 13 seeks action on climate change; SD G 16 aims to foster peaceful and inclusive societies, provide access to justice for all, and build effective, accountable, and inclusive institutions at all levels. These goals are far-reaching, and in addition to political will, they require the kinds of social and cultural paradigm shifts that come from shared educational ideals.

Are the SDGs achievable? How can research on global citizenship education inform education policy and practice that aligns with, supports, and moves us further along the path toward the ambitious agenda the SDGs propose? What knowledge, skills, and behaviours must students learn in order to create a world that cultivates and defends human rights, gender equality, environmental sustainability, peace, and diversity?

\section{A Common Vocabulary}

Before delving into specifics about the potential of global citizenship education to contribute to the 2030 Agenda, I would like to note the complexity of the vocabulary associated with these kinds of educational approaches and goals. Scholars, policymakers, and practitioners employ a variety of terms to describe education that aims to improve society broadly and, more specifically, to do so by fostering local, national, or global citizenship. Some discourses focus on individual citizens and seek to improve behaviour and 'character'. Others include collective efforts to pursue social, political, economic, and 
environmental justice. Just a sampling of relevant terms includes character education, citizenship education, civic education, democratic education, education for democratic citizenship, education for sustainable development, environmental justice education, global citizenship education, human rights education, moral education, service learning, and social justice education. The many terms carry with them different assumptions, emphases, and priorities, and - to make matters more confusing - are often used interchangeably.

So why do I choose to use the term 'global citizenship education' in this chapter? First, global citizenship education is a term often used in international policy documents, along with human rights education, education for sustainable development, and more targeted terms such as gender equality, anti-poverty strategies, and peace (see, for example, UNESCO, 2014b, 2015c, 2016a, 2018d). It has also become a common term among teachers, professors of education, and policymakers interested in citizenship education in both national and international contexts (Ellis, 2016; Gaudelli, 2016; Goren \& Yemini, 2017; Noddings, 2005; Oxley \& Morris, 2013; Schultz, 2017).

Second, a notion of global citizenship education draws attention to the global scope of societal issues such as climate change, economic inequality, or immigration. Global citizenship invokes a kind of pluralistic, multi-ethnic, and multinational ideal - what Martha Nussbaum (2002) calls cosmopolitan citizenship. This ideal, according to Robert Scott (2018, p. 1), emphasises that 'one's identity transcends, even as it respects, geographical and national borders; that one's social, political, environmental and economic actions occur in an interdependent world'. As a universal educational goal, global citizenship education, much like human rights education, seeks to find common ground, despite the various political systems and climates in which students live.

Finally, global citizenship tends toward a more expansive rather than purely legal notion of citizenship. As Meira Levinson (2014a, p. 135) notes, legal citizens 'have rights and privileges accorded or protected by the state, as well as duties toward the state'. Rights, Levinson argues, might include the right to vote, to seek political office, to travel freely, and to be protected by the state from physical harm. At the same time, legal citizens have obligations to the state such as paying taxes and military or jury service. Global citizenship, on the other hand, carries no legal meaning or status, which means one can easily distinguish programmes that teach global citizenship from efforts to prepare youth and adults to pass a national citizenship test or requirement. Among K-16 educators, teaching children, youth, and young adults to be 'good citizens' is most often understood as teaching the knowledge, skills, and social dispositions consistent with living in a community, where people not only get along but also shape the practices, norms, and institutions that define it. Global 
citizens, in this sense, refers not only to those with legal or political status but to all residents of the local, national, and global community.

Although there is some consensus about the broad applicability of the term 'global citizens', there remains a notably broad (and sometimes contradictory) set of related goals and education practices. If educators can agree that schools have an essential role to play in preparing students for informed engagement in civic and political life, they cannot seem to agree on what that requires. The very same efforts that are applauded by some are viewed as misguided by others. The result for school children has been a mostly watered-down notion of citizenship education that emphasises good character and patriotism over critical thinking and engaging with multiple perspectives.

Partly in response to the indistinct definitions I describe above, a significant body of education scholarship is concerned not only with whether students should learn citizenship (global and otherwise) or even how, but also with the range of goals and ideological assumptions underpinning the approaches (Banks, 2008, 2017; Parker, 2003; Ross, 2017; Stitzlein, 2017). It was in that vein of inquiry that colleagues and I began studying programmes and policy in the United States and Canada to better understand what kind of citizens practitioners and policymakers were imagining schools might produce, and the political implications of resulting programme and policy choices (see, for example, Westheimer \& Kahne, 2004; Kahne \&Westheimer, 2006; Westheimer, 2015, 2017).

Our research led us to create a typology of three conceptions or visions of the 'good' citizen to better understand the aims and effects of various programmatic approaches. Since we first proposed the original typology, it has been used by scholars and practitioners in education, political science, sociology, social work, environmental studies, journalism, and public policy, and it has been translated into a dozen languages. Colleagues and other scholars working independently have used this framework to examine educational programmes in, for example, Australia, Canada, England, Hong Kong, Ireland, Israel, Japan, Malawi, Mexico, the Netherlands, New Zealand, Scotland, Singapore, South Korea, and the United States (for example, see Peterson and Bentley, 2017; Ng \& Yuen, 2016; Kennedy, 2007; Grossman \& Cogan, 2012; Mallon, 2018; Zamir \& Baratz, 2013; Namphande et al., 2017; de Groot, Goodson, \& Veugelers, 2014; Wood, Taylor, \& Atkins, 2013; Biesta, 2008; Sim, 2006). Although our work has been conducted primarily (although not exclusively) in North America, it 
seems that the desire to clarify and make sense of the underlying aims of educational programs - including those implemented in response to the SDGs - is global.

Three visions of what it means to be a 'good' citizen emerged from our studies (Westheimer \& Kahne, 2004; Kahne \& Sporte, 2008; Westheimer, 2015): the Personally Responsible Citizen; the Participatory Citizen; and the Social JusticeOriented Citizen (see Table 13.1). I describe these here as a framework for discussing the interrelationship between global citizenship education and the objectives and vision of a better world represented by the UN's 2030 Agenda.

Personally Responsible Citizens contribute to food or clothing drives when asked and volunteer to help those less fortunate, whether in a soup kitchen or a senior centre. They might contribute time, money, or both to charitable causes. Both those in the character education movement and those who advocate community service emphasise this vision of good citizenship. They seek to build character and personal responsibility by emphasising honesty, integrity, self-discipline, and hard work. Or, they nurture compassion by engaging students in volunteer community service.

Participatory Citizens participate in the civic affairs and social life of the community at local, state/provincial, national, and sometimes global levels. Educational programmes designed to support the development of participatory citizens focus on teaching students about how government works, and, in democratic countries, the importance of voting. They also highlight the role of other institutions (e.g., community-based organisations, churches) and encourage students to plan and participate in organised efforts to care for those in need. While the personally responsible citizen would contribute cans of food for the homeless, the participatory citizen might organise the food drive.

The Social Justice-Oriented Citizen is an individual who knows how to critically assess multiple perspectives, examine social, political, and economic structures, and explore strategies for change that address root causes of problems. These are critical thinkers, and this vision of citizenship is the least commonly pursued. Programmes that encourage this form of citizenship emphasise the ability to think about issues of fairness, equality of opportunity, and political engagement (some of the very issues highlighted in the UN's 2030 Agenda). They share with the participatory citizen an emphasis on collective work related to the life and needs of the community. However, they make critical engagement a priority and encourage students to become informed about a variety of complex social issues and look for ways to improve society. These programmes are less likely to emphasise the need for charity and volunteerism as ends in themselves and more likely to teach about ways to effect systemic 
Personally responsible citizen
Participatory citizen Social justiceoriented citizen

Critically assesses social, political, and economic structures

Picks up litter, recycles, Organises community and gives blood efforts to care for those in need, promote economic

Explores strategies for change that address root causes of problems development, or clean

Helps those in need, up environment

lends a hand during times of crisis

Knows how government agencies work

Obeys laws

Knows strategies
for accomplishing
collective tasks

\begin{tabular}{|c|c|c|c|}
\hline $\begin{array}{l}\text { Sample } \\
\text { action }\end{array}$ & $\begin{array}{l}\text { Contributes food to a } \\
\text { food drive }\end{array}$ & $\begin{array}{l}\text { Helps to organise a } \\
\text { food drive }\end{array}$ & $\begin{array}{l}\text { Explores why people } \\
\text { are hungry and acts } \\
\text { to solve root causes }\end{array}$ \\
\hline $\begin{array}{l}\text { Core } \\
\text { assumptions }\end{array}$ & $\begin{array}{l}\text { To solve social } \\
\text { problems and improve } \\
\text { society, citizens must } \\
\text { have good character; } \\
\text { they must be honest, } \\
\text { responsible, and law- } \\
\text { abiding members of } \\
\text { the community }\end{array}$ & $\begin{array}{l}\text { To solve social } \\
\text { problems and improve } \\
\text { society, citizens must } \\
\text { actively participate } \\
\text { and take leadership } \\
\text { positions within } \\
\text { established systems } \\
\text { and community } \\
\text { structures }\end{array}$ & $\begin{array}{l}\text { To solve social } \\
\text { problems and } \\
\text { improve society, } \\
\text { citizens must } \\
\text { question and change } \\
\text { established systems } \\
\text { and structures when } \\
\text { they reproduce } \\
\text { patterns of injustice } \\
\text { over time }\end{array}$ \\
\hline
\end{tabular}

SOURCE: WESTHEIMER (2015)
Seeks out and addresses areas of injustice

Knows about social movements and how to effect systemic change Explores why people are hungry and acts To solve social problems and improve society, citizens must question and change established systems they reproduce patterns of injustice over time 
and lasting change. If participatory citizens are organising the food drive and personally responsible citizens are donating food, social justice-oriented citizens are asking why people are hungry and acting on what they discover to address root causes of hunger (for example, poverty, inequality, or structural impediments to self-sufficiency).

\section{Personal Responsibility Is Not Enough}

More than a decade of studies by scholars in a broad variety of geographical, political, economic, and social contexts (see Westheimer, 2015 for review) come to similar conclusions: The kinds of goals and practices commonly represented in citizenship education programmes usually have more to do with volunteering, charity, and obedience (personally responsible citizenship) than with social action, social change, or sustainability (participatory and social justice-oriented citizenship). In other words, good citizenship - to many educators and policymakers - means listening to authority figures, dressing neatly, being nice to neighbours, and helping out at a soup kitchen, rather than grappling with the kinds of social policy decisions needed to build a more sustainable and just world.

Many school-based programmes that take the time to teach citizenship are the kind that emphasise either good character - including the importance of helping those in need - or technical knowledge of legislatures and how government works. Far less common are school programmes that teach students to think about root causes of problems or challenge existing social, economic, and political norms as a way of improving society. When we deny students the opportunity to consider paths for change that involve a critical examination of collective social, political, and economic questions (and not just individual character), we also betray important principles of good governance (see, for example, the UN's 203o Agenda [UNGA, 2015b, paras. 9, 20, 35, and 44], political participation [paras. 19 and 20], and the need for citizens to be able to engage as critical agents with informed critique to make collective choices [para. 51]).

The 2030 Agenda's call for transformative change requires that educators engage students in efforts to understand structural change and not just personal responsibility. Although the sustainable development goals are rightly ambitious, I see at least three vulnerabilities that place at risk their transformative potential: the preference for apolitical conceptions of citizenship in global citizenship education programs (citizenship without politics); calls for youth empowerment with little attention to issues of control and authority 
(empowerment without power); and a vision of sustainable development unmoored from norms of representative governance (sustainability without democracy).

\subsection{Citizenship without Politics}

There is a parable about a small village by a river. One day the villagers were working in fields by the river when a woman notices a baby floating downstream. She yells out and someone runs into the river and rescues the baby. One neighbour provides clothes, another food, and so on. The next day, the same villagers are working by the river. They see two babies floating downstream and rescue them. The following day it is four babies and after that eight. Within a short time, practically the entire village is wading into the water, rescuing babies, clothing them, feeding them, trying to find others who will house them, and then returning to rescue more. After a week of rescuing hundreds of babies, one villager yells out, 'Hey! Why don't we go upstream and find out how all these babies are falling into the river?' The others quickly reject the suggestion, saying that there are too many babies in the river, and everyone should continue rescuing them lest they drown.

The moral of the story? Volunteering and providing services for those in need is important. But providing those services without also looking at the root causes of the problem - looking upstream - makes little sense. Personal responsibility and even participating with others to organise a response to a social problem is admirable but inadequate if we do not also look at the structural causes that are creating the need for direct service in the first place. Character traits such as honesty, integrity, and responsibility for one's actions are certainly valuable for becoming good neighbours and citizens. But, on their own, they have little to do with the unique requirements of the kind of community and global citizenship engagement that promotes the types of structural and sustainable changes that underpin the UN's 2030 agenda. Some programmes actually promote volunteering and charity as an alternative to social policy and organised government action. For example, former US President George H. W. Bush famously promoted community service activities for youth by imagining a 'thousand points of light', representing charitable efforts to respond to those in need (Bush, 1988). But if young people understand these actions as a kind of noblesse oblige - a private act of kindness performed by the privileged - and fail to examine the deeper structural causes of social ills, then the thousand points of light risk becoming a thousand points of the status quo. The kind of global citizen that can work with others to 'transform our world' as envisioned in the 2030 Agenda (UNGA, 2015b) may be a kind and decent person, but will also need to be significantly more; an overemphasis on 
kindness might even discourage challenges to the status quo so as not to ruffle feathers.

Education that teaches students to follow the rules, obey authority figures, be honest, help others in need, clean up after themselves, try their best, and be team players is rarely controversial. But without an analysis of power, politics, and one's role in local and global political structures - and without showing students how they can work with others toward fundamental change - students will be unlikely to become effective citizens who can transform their communities and the world by addressing issues identified by the 2030 Agenda such as poverty, hunger, and inequality. Through an examination of inequities, both historical and extant, programmes that emphasise participatory and social justice-oriented visions of the 'good' citizen can also enable reflection on the ways overlapping and intersecting categories such as race, class, gender, and sexuality can constrain and enable social action for the collective benefit of all.

Although any approach to SDG 4 must be broad enough to account for global political diversity, if we are to take seriously the transformative aspirations of the 2030 Agenda, we must consider teaching and learning activities that make participation and the quest for social justice possible. Programmes that privilege individual acts of compassion and kindness often neglect the importance of social action, political engagement, and the pursuit of just and equitable policies. The vision promoted is one of citizenship without politics or collective action - a commitment to individual service, but not to social justice.

\subsection{Empowerment without Power}

I opened this chapter with a quotation from George Counts's famous $193^{2}$ speech before the Progressive Education Association, Dare the School Build a New Social Order? In that same speech, Counts went on to argue that capitalism is cruel and inhumane, and that it 'has exploited our natural resources without the slightest regard for the future needs of our society; it has forced technology to serve the interests of the few rather than the many' (Counts, 1932, p. 47). His speech and subsequent publication carefully spelled out political, economic, and social forces that had to be challenged through education if society were to be improved or 'transformed'. It addressed directly the power relations at play in any serious effort to realign those forces. For example, zeroing in on economic power differentials, Counts spoke of a democratic tradition of governance that had run up against a kind of industrial feudalism marked by massive inequality. 'Unless the democratic tradition is able to organize and conduct a successful attack on the economic system', Counts argued, 'its 
complete destruction is inevitable. If democracy is to survive, it must seek a new economic foundation' (Counts, 1932, p. 45).

Transforming Our World: The 2030 Agenda for Sustainable Development was penned at a time of rising economic inequality at levels not seen since the Great Depression, which was when Counts delivered his 1932 speech. Yet, while the word 'power' appears 28 times in Counts's 11,ooo-word pamphlet, it appears exactly once in the 15,00o-word UN's 2030 Agenda (UNGA, 2015 b). The ways in which politics and inequality might affect efforts toward sustainable development are similarly absent. 'Empower', on the other hand, appears at least 15 times. Empowerment without a discussion of power, politics, or inequality is an incomplete discussion at best, an insidious one at worst. For sustainable development education and goals to flourish, education reform will need to promote a conception of global citizenship that furthers not only personal responsibility and participation but also the ability to grapple with conflicting interests, social movements, and social change. The historical answer to Counts's Dare the Schools Build a New Social Order? has mostly been 'no'. But I want to take the aspirational goal of transformation seriously. The promise to Transform Our World, in part through education, will require grappling with the competing ideological agendas inherent in unconstrained economic growth, neoliberal concentrations of wealth and poverty, nonrepresentative forms of government, and instrumental visions of education that privilege economic competitiveness, high stakes assessments, and rule-following over critical thinking and human development.

\subsection{Sustainability without Democracy}

Early in the 2030 Agenda, the authors note that 'democracy, good governance and the rule of law ... are essential for sustainable development' (UNGA, 2015b, p. 5). It is the one and only use of the word 'democracy' or any of its variants in the 15,000-word document. The only other reference to the right of self-governance appears in SD G 16, which calls for ensuring 'responsive, inclusive, participatory and representative decision-making at all levels' (UNGA, 2015b, p. 28). The reasons for the decoupling of the right to self-governance from more universal notions of human rights and sustainability are a matter of political compromise. The SDGs are universal and are intended to be implemented by and in all countries whether democratic, totalitarian, theocratic, or otherwise. That makes an explicit demand for democratic governance impossible. Yet, even a more elastic conception of democratic principles is difficult to square with the well-known limits of international standards. But if the 2030 Agenda 
must necessarily fall short of a call for democracy as a prerequisite for sustainability, equality, and justice, it could support participatory and social justice-oriented education through a more robust exploration of the power that democratic representation, in its ideal form, represents.

A vision of citizenship that makes little or no reference to political representation risks relegation to liberal platitude. This could explain the preference in United Nations documents for the term 'global citizenship education' over 'citizenship education' or 'education for democratic citizenship'. Global citizens, after all, do not vote. They do not set social, economic, or political policy or have any representation on any local, national, or global governing body. The predilection for a notion of citizenship unmoored from a pesky need for representation is especially worthy of concern in a time of threats to even established democratic countries of the Global North. In a widely circulated 2017 report, the Pew Research Center raised considerable alarm among those who have generally assumed that Western democracies enjoy relative stability amidst an entrenched culture of democratic governance. Although the report was entitled Globally, Broad Support for Representative and Direct Democracy, commentators, civic educators, and political scientists highlighted a number of findings that challenged the rosier title. In the United States, for example, $22 \%$ of respondents thought that a political system in which a leader could make decisions without interference from Congress or the courts would be a good way of governing. Almost half of US millennials thought the same (globally, that figure was 26\%) (Wike et al., 2017).

In another study released a few months earlier, Harvard lecturer Yascha Mounk and Australian political scientist Roberto Stefan Foa examined longitudinal data from the World Values Survey and found that between 1995 and 2014, the number of people who reported a preference for a government leader who did not need to bother with elections increased in almost every developed and developing democracy. Again, the growth has been greatest among youth and young adults (Mounck \& Foa, 2016; Foa \& Mounk, 2016). Social media echo chambers further entrench antidemocratic tendencies and pollute genuine social and political discourse (Bonikowski, 2017; Kahne \& Bowyer, 2017; UN, 2016). Yoichi Funabashi, chairman of the Rebuild Japan Initiative (dedicated to strengthening democratic ideals in Japan) summarises the risks succinctly: 'If society becomes characterized by intolerant divisions, in which people immediately select their allies and dismiss others as foes based on such criteria as race, ethnicity, religion or lifestyle, then democracy's foundational principles, rooted in careful deliberation and compromise, will be rendered inoperable' (Funabashi, 2017). 
In the remaining space, I highlight three successful approaches that encourage students to imagine a more just and sustainable world and give them the tools to achieve it. Although I use classroom examples to better ground my arguments in the context of classroom life for students and teachers, I hope these descriptions clarify for policymakers, reformers, government and civil society actors, and others the conditions required for teachers to effect meaningful change. The inevitably loose coupling between broad vision statements such as those represented in the SDGs and on-the-ground education reform can be made tighter only through the demonstration of real-world examples.

\subsection{Teach Students to Question}

Citizens who do not question cannot be stewards of the kind of socially, politically, and economically just society that the 2030 Agenda envisions. One hallmark of a vulnerable society is the notion of one single 'truth' (one history, one policy choice, one leader, and so on). In some places, questioning that truth may be discouraged; in others, it may be illegal. But education for global citizenship teaches students how to ask challenging questions, the kind of uncomfortable queries that challenge tradition (Giroux, 2017). Although most of us would agree that traditions are important, history demonstrates that progress often comes only from questioning the way things are. Dissent - feared and suppressed in closed societies - is the engine of progress in free ones. International standards and global school reform efforts should do everything possible to ensure that teachers and students have opportunities to ask these kinds of questions.

For example, Bob Peterson, a one-time Wisconsin Elementary Teacher of the Year, worked with his students at La Escuela Fratney in Madison, Wisconsin, to examine the full spectrum of ideological positions that emerged following the September 11, 2001, terrorist attacks. Instead of avoiding his fifth-grade students' challenging questions, Peterson encouraged them. He placed a notebook prominently at the front of the classroom labelled 'Questions That We Have'. As the students discussed their questions and the unfolding current events, Peterson repeatedly asked students to consider their responsibilities to one another, to their communities, and to the world (Westheimer, 2015).

\subsection{Expose Students to Multiple Perspectives}

Much as Darwin's theory of natural selection depends on genetic variation, any theory of robust global citizenship education depends on encouraging a multiplicity of ideas, perspectives, and approaches to exploring solutions to 
issues of widespread concern. Mechouat (2017), for example, writing about citizenship education in Morocco, argues that in order to strengthen society, in particular with regard to gender equality, civic education must encourage students' freedom of expression, which in turn increases their engagement with diverse ideas. Students need practice in entertaining multiple viewpoints on issues that affect their lives (Bruen et al., 2016; Campbell, 2008; Lin, Lawrence, \& Snow, 2015). These issues - sustainability versus economic growth, for example - might be controversial. But improving society requires embracing that kind of controversy so citizens can engage in dialogue and work together toward understanding and enacting sensible policies.

Why would we expect adults, even politicians, to be able to intelligently and compassionately discuss different viewpoints in the best interests of their constituents if schoolchildren never or rarely get that opportunity? In schools that further the kinds of goals represented by the SDGs, teachers engage young people in deep historical, political, social, economic, and even scientific analysis. They also challenge children to imagine how their lived experiences are not universal and how issues that may seem trivial to them could matter deeply to others. They have students examine multiple perspectives not only to know that their (or their parents') views may not be shared by everyone but also to engender a critical empathy for those with competing needs. Perspective-taking also introduces students to intersectionality and the ways in which people's diverse experiences shape their worldviews and priorities. Teaching students that their experience is not universal - and is in fact very specifically situated by race, class, gender, economic status, and so on - allows them to consider and encourage efforts to protect all members of a community, rather than just those who look and live like them. This is the kind of teaching that encourages future citizens to leverage their civic skills for the greater social good, rather than their own particular interests, thus working to challenge social inequities.

For example, teachers might be encouraged to present newspaper articles from around the world (easily accessed through the internet) that examine the same event. Which facts and narratives are consistent? Which are different? Why? Textbooks from several different countries could provide another trove of lessons on multiple viewpoints and the role of argument and evidence in deliberation. For instance, in the English-language context, schools in Canada, the United Kingdom, and the United States present strikingly different perspectives on the War of 1812. Why not also ask students to research who wrote their textbook? Was it one person or a committee? Why were those people chosen? What kind of author was not invited to participate? The idea that a person or group actually wrote a textbook reminds us that the words are not sacrosanct but represent the views of a particular time, place, and group of 
authors. These approaches help demonstrate to students that 'facts' are less stable than is often thought.

Students should also examine multiple perspectives on controversial contemporary issues. Students are frequently exposed to past historical controversies, such as slavery, Nazism, or laws denying voting rights to women, that are already settled in the minds of all but a small fringe minority. But those same students are too often shielded from matters that require thoughtful engagement with today's competing ideas. That kind of engagement is exactly what global citizenship requires.

\subsection{Focus on the Local}

Despite the global ambitions of SDG 4, teachers should be encouraged to have students consider their specific surroundings and circumstances for meaningful education on sustainable development. It is not possible to teach civically engaged thinking that could lead to transformative change without providing a specific context and environment to think about. For that reason, among many others, nationally or internationally standardised tests are difficult to reconcile with in-depth critical thinking about issues that matter to students in a particular time and place. In many jurisdictions, ever more narrow curriculum frameworks emphasise preparing students for standardised assessments in mathematics and literacy at the same time that they short-change the social studies, history, and even the most basic citizenship education ( $\mathrm{Au}$, 2007; Koretz, 2017). Not only do children learn less, what they learn tends to follow prescriptive formulas that match the standardised tests. In the process, more complex and difficult-to-measure learning outcomes are left behind. These include creativity and emotional and social development but also the kinds of thinking skills associated with robust civic engagement. Teachers' ability to teach critical thinking and students' ability to think and act critically are diminished as the uniformity demanded inhibits the possibilities of using localised knowledge (Meier \& Gasoi, 2018; Blankstein \& Noguera, 2016; Strauss, 2012). Similarly, Pineda's (2010) study of standardised testing in Mexico and Argentina demonstrates the ways in which such tests ignore local and indigenous knowledge, stifle creativity, and exacerbate social inequality by locking students in particular tracks in the labour economy. Curricular approaches that spoon-feed students to succeed on narrow academic tests teach students that broader critical thinking is optional.

Although the overall international reform context may limit in-depth, critical analysis, a significant number of teachers continue to teach those skills. As the important work of Kahne and Middaugh (2008) has demonstrated for the US, however, it tends to be higher-achieving students, often from wealthier 
neighbourhoods, who are receiving a disproportionate share of the kinds of citizenship education that sharpen students' thinking about issues of public debate and concern. This demographic divide or 'civic opportunity gap' results in unequal distribution of opportunities to engage civically and in thoughtful ways.

One way to provide experiences with participation in civic and political life is to engage students in community-based projects that encourage the development of personal responsibility, participation, and critical analysis. Community-based service activities (Kahne \& Westheimer, 2001; Evans, 2015) can foster the knowledge, skills, and dispositions of engaged, global citizens. Similarly, recent work on action civics is a particularly powerful and thoughtful way to foster civic participation that transcends community service to also include a focus on government, politics, and policy (Blevins, LeCompte, \& Wells, 2016; Levinson, 2014b). When students have the opportunity to engage with civics education through direct action in their own local context, the impacts of their work are integrated with their lived experience and can teach fundamental lessons about the power of citizen engagement (Facing History and Ourselves, 2018; Obama, 2018).

Of course, choosing to be explicitly political in the classroom can cause friction for teachers - with students, parents, and administrators. Teachers have been disciplined, suspended, and fired for engaging students in discussions of controversial issues (Journell, 2017; Stitzlein, 2013; Westheimer, 2007). Even when teachers avoid expressing their own political views, encouraging discussion, controversy, and action in the classroom can be daunting. Students may express views that make classmates uncomfortable; they may engage in political acts that concern their parents; or they may choose to challenge their own school's policies. Education aimed at transformation can be messy. Rather than let fear of sanction and censorship dictate pedagogical choices, however, local, national, and global policymakers should support and protect teachers and enable them to use debates and controversy as 'teachable moments' in civic discourse.

\section{Can Education Transform Our World?}

In her influential book, The Way We Argue Now (2006), literary theorist Amanda Anderson argued that questions about how we should live should be central to literary criticism. I find the same to be true for education. Schools can serve to promote peace, equality, sustainability, public health, and many if not all of the remaining sustainable development goals over the long term. 
But to do so, educators must be enabled to include those goals in the fabric of the school curriculum and broader mission; education must be seen as more than an engine of the economy; and teachers must be allowed to build school cultures that impel students to envision a better world and to learn the knowledge, skills, and dispositions required to make that world possible. At a time when national borders and identities are increasingly blurred, contested, and crossed, a transnational or cosmopolitan civic identity is also needed. We are sustainable only to the extent that we learn to sustain one another.

Citizenship education is not a new idea. For as long as there has been public education, schools have taught lessons in citizenship, moral values, good behaviour, and 'character' (Dewey, 1909; Draper, 1858; Fahey, 1916; Mosier, 1965; Tyack \& Hansot, 1982). Even before there was formal schooling, informal education was replete with such goals (Heater, 2015; Spring, 2018). Today's schools, regardless of country, inevitably teach these lessons as well. For example, schools teach children to follow rules, to wait their turn, and (ideally) to cooperate with others. Schools (again, ideally) teach children how to acquire and process information and how to articulate their ideas to others - all necessary skills for civic participation. Some schools also help students consider whether being a 'good' citizen ever requires questioning rules, or what might be the proper balance between rule-following and thinking about the origins and purposes of rules. Global citizenship education that aims to foster just and sustainable societies will require that students learn to think critically, ask questions about the world around them, and engage with multiple ways of seeing and perceiving. Public policies - local, national, and global - that support these efforts are the key to making SDG 4 effective.

At a time of rising economic inequality and widespread fear, xenophobia, attacks on a free press, and dangerous forms of populism, teaching and learning that helps young people understand and respond to these phenomena is essential. The UN's 2030 Agenda for Sustainable Development outlines bold goals that universal education can help meet. Basic skills like literacy and numeracy are, perhaps, the first important step, but they are not enough. A sustainable and just global society requires that children and youth gain the knowledge, capacities, and dispositions associated with a robust, civically engaged life. 